\title{
A Neo-Institutional Perspective on Ethical Decision-Making
}

\author{
Christopher Chan, PhD \\ Associate Professor in Human Resource Management \\ School of Human Resource Management \\ York University \\ 4700 Keele Street, Toronto, Ontario, M3J 1P3, Canada \\ Tel: +1-416-736 2100 ext.30593 \\ Fax: + 1-416-736 5188 \\ E-mail: cristoph@yorku.ca \\ Honorary Research Fellow \\ Faculty of Business \\ Australian Catholic University \\ North Sydney Campus (MacKillop)
}

Level 4, 21 Berry Street, Sydney, New South Wales, 2060, Australia

Visiting Associate Professor

Institut de Gestion de Rennes

Université de Rennes 1

11 rue Jean Macé, 35708, Rennes, Cedex 7, France

and

Subramaniam Ananthram, PhD*

Senior Lecturer - International Business

School of Management

Curtin Business School

Curtin University

Kent St, Bentley

Western Australia, 6102

Australia

Tel: 61892661312

Fax: 61892667897

Email: S.Ananthram@curtin.edu.au

*corresponding author

A preliminary version of this paper was accepted for presentation at the $10^{\text {th }}$ Asia Academy of Management Conference, Fukuoka, Japan, 2017. 


\title{
A Neo-Institutional Perspective on Ethical Decision-Making
}

\begin{abstract}
Drawing on neo-institutional theory, this study aims to discern the poorly understood ethical challenges confronted by senior executives in Indian multinational corporations and identify the strategies that they utilize to overcome them. We conducted in-depth interviews with 40 senior executives in Indian multinational corporations to illustrate these challenges and strategies. By embedding our research in contextually relevant characteristics that embody the Indian environment, we identify several institutional- and managerial-level challenges faced by executives. The institutional-level challenges are interpreted as regulative, normative and cognitive shortcomings. We recommend a concerted effort at the institutional and managerial levels by identifying relevant strategies for ethical decision-making. Moreover, we proffer a multi-level model of ethical decision-making and discuss our theoretical contributions and practical implications.
\end{abstract}

Keywords neo-institutional theory, ethical decision-making, multinational corporations, institutional isomorphism

“Earth provides enough to satisfy every man's need, but not every man's greed." - Mahatma Gandhi

\section{Introduction}

How do executives handle the difficult ethical challenges associated with decision-making in multinational corporations (MNCs)? Ethical decision-making is a complex phenomenon (Grojean, Resick, Dickson, \& Smith, 2004). The pursuit of understanding ethical decisionmaking has garnered widespread interest from scholars in numerous disciplines; 
anthropologists, business scholars, philosophers, ethicists, sociologists, psychologists, social workers and theologians alike have offered unique insights into how ethical decision-making can be understood and encouraged (Chan-Serafin, Brief and George, 2014; Crossan, Mazutis and Seijts, 2013; McAuliffe, 2012; Treviño, Weaver and Reynolds, 2006; Weaver and Agle, 2002). Although there is limited consensus, a central theme is the critical role of leadership in determining the ethical climate of organizations (Grojean et al., 2004; Li, Chun, Ashkanasy and Ahlstrom, 2012). Indeed, leaders play a critical role in setting the ethical tone for their organizations (Schwartz, 2013; Srinivasan, 2011). Their positional authority or power over policies, processes, expectations and outcomes can communicate the ethical values that they uphold and can affect how employees respond to them (Brown and Mitchell, 2010). Thus, some studies have in turn shown a relationship between ethical leadership and employee behavior (Al-Khatib, Rawwas and Vitell, 2004; Fyke and Buzzanell, 2013).

Notwithstanding the contributions of this work, there is limited understanding of ethical decision-making in Indian MNCs. Given that these MNCs are becoming quite large in terms of their scale of operations, influence, and number of employees and other stakeholders with whom they interact (Chakraborty, 1997; Kohls and Buller, 1994), it is crucial to understand the strategies and approaches used by organizational leaders to address the ethical challenges. Moreover, India's transformation from a highly centralized economy to a relatively decentralized market-based economy in the 1990s has revolutionized several industries (Bhowmik, 2009; Wu, 2009). However, there are still remnants of a bureaucratic system that is laden with corruption, bribery and other forms of unethical practices (The World Bank, 2012; Transparency International, 2015a; Srinivasan, 2011; Vittal, 2003). In such a bureaucratic and highly politicized environment, it is often difficult for Indian business leaders to engage in ethical decision-making (Chakraborty, 1997; Fernando, 2009; Wu, 2009). Furthermore, this ethical dilemma poses tremendous challenges to business operations, productivity, investors' 
confidence and investments, equity, fairness, social cohesion, and economic and political stability (Arjoon, 2000; Hartman, 1998; Nichols, 2009). Given this limited understanding, we seek to contribute to the extant literature by studying the ethical challenges faced and the strategies used by Indian executives to make decisions in a complex environment.

Institutional forces have tremendous bearing on ethical decision-making; therefore, neo-institutional theory is considered a suitable theoretical lens to study this process. The theory posits that organizations are subjected to environmental forces to which they must adapt if they are to compete and survive (Björkman, Fey and Park, 2007; DiMaggio and Powell, 1991; Hearn, 2015; Nell, Puck and Heidenreich, 2015; Scott, 2001; Süß and Kleiner, 2008). Neoinstitutional theory views these adaptations as a reaction to institutional pressures under the guise of rationality to gain legitimacy (Suddaby, Seidl and Lê, 2013). For instance, it is plausible that organizational actors engage in questionable business practices as a result of external pressures by rationalizing the futility of opposing a corrupt system (Young, Ahlstrom, Bruton and Rubanik, 2011). These forces, called "institutional isomorphisms" (DiMaggio and Powell, 1983), include coercive isomorphism (e.g., pressures from political institutions and unions), mimetic isomorphism (e.g., best practices that compel organizations to conform) and normative isomorphism (e.g., professional norms set by various professional bodies).

India's various institutions, such as political, legal, economic and socio-cultural (including religiosity and spirituality) systems, professional bodies, social pressures and cultural norms, arguably have a significant effect on ethical decision-making. Yet, Cordeiro, Galeazzo, Shaw, Veliyath and Nandakumar (in press) claim that there exists an 'institutional void,' where the legal system is cumbersome albeit being well-developed. Cooke and Saini (2015) provide another example of this void, where Indian industrial relation institutions are generally unable to address labor disputes, which tips the balance of power in favor of either management or employers, depending on their relative power and connections locally. Thus, 
we aim to identify the pertinent institutional (isomorphic) forces that affect Indian MNCs and how they might affect Indian executives' decision-making process, especially with respect to ethical issues.

We contribute to the interface between neo-institutional theory and business ethics in India by answering the following two research questions. First, what are the ethical challenges faced by senior Indian business leaders in their decision-making in a complex environment? Here, we unravel the factors that contribute to the isomorphic forces that these executives perceive to be responsible for ethical challenges. Second, which strategies do these executives perceive to be effective in dealing with those challenges? These questions respond to Voegtlin, Patzer and Scherer's (2012: 2) observation that current studies on ethical leadership "do not adequately encompass the causes and implications of present leadership challenges," especially considering the economic and moral implications of globalization "with regard to the individual's actions as well as their organizational and social embeddedness." We utilize indepth interview data from 40 Indian executives in MNCs to illustrate the challenges that they face and the strategies that they use.

Our study makes theoretical and empirical contributions and provides implications for practice. We contribute to neo-institutional theory by providing a fine-grained explanation of the sources of institutional challenges and identify solutions for ethical decision-making, thereby extending its applicability to ethical decision-making. Our findings stress the importance of not only the legal and socio-cultural institutions but also those of educational and family institutions on ethical decision-making. The importance of educational and family isomorphisms have rarely been mentioned in neo-institutional theory. These findings not only echo previous studies (e.g., Nair, Guldiken, Fainshmidt and Pezeshkan, 2015; Pant and Ramachandran, 2017; Shirodkar and Mohr, 2015) that claim the existence of weak institutions in India but reveal how they manifest in the lives of MNCs and key decision-makers. In doing 
so, we argue that a return to India's customs and values that emphasize virtues may help individuals and organizations to remain cognizant of their ethical responsibilities and behaviors. Moreover, our findings provide an empirical contribution as we validate our findings in an Indian MNC context and proffer a multi-level model of ethical-decision for further testing and validation in other emerging economies. Further, our findings have implications for public administration, management practices and individual decision-making. Given the various barriers that stem from multiple sources, we argue that the solutions have to be multidimensional. Public organizations need to collectively acknowledge the existence of corruption and stamp it out. Organizations also play an important role in fostering ethical decision-making via corporate training, enforcing codes of conduct and conducting ethical audits, just to name a few approaches. Individual leaders are and should be held responsible for setting the ethical tone for their organizations. Thus, ethical decision-making demands a concerted effort that involves multiple stakeholders (institutions and individuals) who believe that ethics are non-negotiable.

\section{Theoretical Background}

\section{Neo-institutional Theory}

Neo-institutional theory posits that an organization's environment exerts certain pressures that will compel it to adapt so that it can remain competitive and survive (DiMaggio and Powell, 1991; Nell et al., 2015; Rosenzweig and Singh, 1991). According to Selznick (1948), who is considered the founder of institutional theory, various actors have the capacity to restrict rationality in decision-making. Thus, an organization's internal environment (e.g., human resources, policies and leadership) and external environment (e.g., political system, economic system and legal system) can shape its direction. For example, it is clear that the prevalence of individual personalities, personal interests, unique habits, and outside commitments means 
that it is sometimes difficult to be single-mindedly aligned to an organization's goals (Aßländer, Roloff and Nayir, 2016; Balakrishnan, Malhotra and Falkenberg, 2017). In addition, socio-political forces influence organizations, as in the case of the shift from highly centralized and administered economic policies to a relatively decentralized and market-based system (Bhowmik, 2009; Sun, Peng and Tan, 2017), which is the case for India.

DiMaggio and Powell $(1983,1991)$ conceptualize these environmental pressures as "institutional isomorphism" (i.e., various pressures internal and external to an organization that have potential to shape the organization's goals and directions) and identify three such isomorphisms: coercive, mimetic and normative. "Coercive isomorphism" includes regulatory pressures from the political and legal systems in the form of environmental protection legislations, tax laws, employment laws and so forth. Despite economic reforms in the 1990s, the Indian government still plays a relatively strong role in many sectors, such as manufacturing, infrastructure and education (Nair et al., 2015). The government continued with further tweaks in the 2000s. For example, Ashwin, Krishnan and George (2015) argued that in order to compete with foreign firms, Indian pharmaceutical companies had to increase their research and development spending after the government passed the Indian Patent Act (2005). Environmental uncertainty may compel some organizations to mimic or adopt certain best practices (e.g., quality programs, employee training and development programs, Six Sigma, and codes of conduct) in the hope of achieving competitiveness, which is termed "mimetic isomorphism." Professional norms established by various professional bodies (e.g., accounting bodies, engineering bodies, and medical associations) fall under "normative isomorphism," which has potential to affect the various areas pertaining to human resource management (e.g., minimum educational qualification requirements, compensation, promotion, recruitment and selection processes, continuous training and certification). These isomorphisms are referred to as "regulative elements," "normative elements" and "cultural/cognitive elements" (Scott, 
2001). Taken together, these isomorphisms have the capacity to homogenize organizations, their policies, their operating procedures and their human resources (DiMaggio and Powell, 1983). From neo-institutional perspectives, organizations can proactively establish legitimacy by adopting certain strategies that will compel other organizations to follow suit (Peng, 2002; Powell, 2007). For example, companies that deliberately collaborate with government institutions gain acceptance and trust, thereby increasing their legitimacy (Beddewela and Fairbrass, 2016). However, Prashantham and Dhanaraj (2015) allude that Indian MNCs often rely more on relationships because of the prevalence of weak institutions but this notion contradicts numerous studies (e.g., Nair et al., 2015; Pant and Ramachandran, 2017; Shirodkar and Mohr, 2015) that claim that India's political institution exerts tremendous isomorphism. It is, therefore, necessary to examine at a fine-grained level whether political and other institutions influence key decision makers when it comes to ethical decision-making, and if so, how?

\section{Ethical Decision-Making}

Neo-institutional isomorphism influences ethical decision-making. Executives rationalize and accept that unethical practices are a means of achieving a competitive edge in an environment that is characterized by high uncertainty and rampant corruption (Collins, Uhlenbruck and Rodriguez, 2008). Hearn (2015) and Nell et al. (2015) note that some MNCs' subsidiaries engage in political activism to gain this edge through political legitimacy (coercive isomorphism). Thus, corruption can take on a self-reinforcing cycle when public officials expect bribes in exchange for certain approvals (e.g., permits, clearances and grants), and those executives are willing to perpetuate this phenomenon when both parties perceive that its personal benefits outweigh its costs (Rodriguez, Siegel, Hillman and Eden, 2006; Rodriguez, Uhlenbruck and Eden, 2005). Similarly, Ufere, Perelli, Boland and Carlsson (2012, p. 2440) 
report that founders and CEOs in various industries were often culprits by subscribing to a set of "bribery best practices." Adopting best practices (mimetic isomorphism) to reduce the costs of production, for example, might tempt individuals to scout for unscrupulous suppliers that have very little regard for environmental protection and employee welfare. Moreover, the normalization of professional standards and codes of conduct (normative isomorphism) plays an important role in promulgating appropriate standards of behavior expected of members and may include expulsion from a professional body and a subsequent ban from engaging in professional activities when individuals are caught transgressing those codes through unethical behaviors (Collins et al., 2008). Therefore, the three types of isomorphisms have an important bearing on individual and organizational behavior.

Because the individual and organizational factors pertaining to ethical behavior are often related, it is imperative to understand them. For example, individuals with selftranscendence values tended to choose more socially responsible behavior than individuals with self-enhancement values (Crilly, Schneider and Zollo, 2011; Egri and Herman, 2000). Personality traits, such as conscientiousness and agreeableness, have been linked to ethical leadership (Kalshoven, Den Hartog and Hoogh, 2011). Some studies focusing on age and ethical behavior report a positive relationship between the two (Borowski and Ugras, 1998; Conroy and Emerson, 2004). Luthar and Karri (2005) observe that individuals exposed to ethics education tend to be more sensitive about ethical behavior, with women exhibiting greater sensitivity toward ethical issues than men. In addition to gender difference, Beekun, Stedham, Westerman and Yamamura (2010) report that women tend to rely on both justice and utilitarianism when making moral decisions, whereas men depend only on justice. However, there are also studies that report a non-significant difference between genders (Derry, 1989; McNichols and Zimmerer, 1985). An external locus of control has been positively related to moral disengagement and transgressions (Tsai, Wang and Lo, 2014). Additionally, an external 
locus of control has been argued to encourage pro-social rule breaking behavior in the furtherance of organizational interests (Vardaman, Gondo and Allen, 2014). Other studies have discovered that ethical leadership influences an organization's ethical climate, which in turn has great potential to promote ethical behaviors among its members (Kuntz, Kuntz, Elnkov and Nabirukhina, 2013; Lu and Lin, 2014). Overall, these studies lend support to neo-institutional theory and demonstrate that individual and organizational factors have important ramifications for individuals' ethical behavior.

Studies have also focused on macro-level factors such as external stakeholders, culture and socio-political environment in relation to ethical decision-making (Arjoon, 2000; Collins et al., 2008). Buckley (2013) argues that managers should avoid the myopic satisfaction of shareholders' interest, which is purely profit driven and can lead to profitability through unethical means, and also consider various stakeholders' interests. Investigating the role of culture in business ethics, Mensah (2014) finds that perceived corruption was low in AngloSaxon culture compared to other European clusters. Political institutions also play an important role in the business-government interface, especially in areas such as corporate tax, laws governing business operations, employment laws, environmental laws and so forth (A $\beta$ länder, 2011; Nair et al., 2015; Wu, 2009). Recent studies tend to adopt an integrative approach by considering an organization's internal and external environments (e.g., Buckley, 2013; Fyke and Buzzanell, 2013; Schwartz, 2013). These findings provide further underpinning for the relevance of neo-institutional theory, particularly institutional isomorphism.

In the context of Indian business ethics, some researchers offer an array of explanations for the uniqueness and prevalence of indigenous ethical values, emphasizing the role of context. Chattopadhyay (2012, p.119) provides an extensive list of Indian values, including "nishtha (sincerity), samarpana (commitment), kartavya-parayanta (responsibility), aparigraha (nonpossession), brahamcharya (moral conduct), jigyasa (curiosity to learn), kauslam (efficiency), 
vividha (innovation), samatva (impartiality), satyam (truth), shivam (righteousness) and sundaram (beauty)" and argues that these values are beneficial for corporate governance. Furthermore, several scholars argue that the foundation of business ethics in India is the concept of virtue ethics (Ananthram and Chan, 2016; Chattopadhyay, 2012; Fernando, 2009; Srinivasan, 2011). India is generally thought to espouse an ethos of ethics, however Patel and Schaefer (2009) believe that the displacement of an indigenous ethical system, values and practices with that of the colonial administrators has wreaked havoc on processes that have served India well for millennia. Although this claim shifts the blame to India's colonial master, Great Britain, there is evidence of unethical practices in organizations originating in countries where colonization is not a factor, such as Thailand and Nepal (Transparency International, 2015b). Therefore, we contend that weak institutions in India, as espoused by Cleveland, Favo, Frecka and Owens (2009), coupled with greed (where individuals believe that the benefits derived from unethical behaviors outweigh their costs and act upon this belief) are largely the bases of the ethical and moral bankruptcy.

Other researchers sought to provide nuances to unethical decision-making in India and how to curb those practices at the top management level. For instance, the prevalence of a slow and cumbersome government bureaucracy with lax enforcement means that top management usually relies on money (which suggests bribes or other forms of payment) and connection to facilitate business transactions (Ardichvili et al., 2012). When such connections are strong between top management and the government, Collins et al. (2008) found that there is a higher probability of corruption, which management rationalized as being necessary to be more competitive. Berger and Herstein (2014) reasoned that the collectivistic nature of Indian society means that utilitarian ethics are applied where relationships take precedence and might even be used to justify unethical practices. These findings allude to the fact that governments and competitors exert isomorphic forces on top management's behavior. Indeed, Indian MNCs 
have to be proactive in providing in-house training to address ethical issues and use of code of ethics (Agrawal, 2017; Srinivasan, 2011).

Despite the existence of research efforts to understand how ethical leadership functions, most studies focus on individual-level issues, and there often is a lack of integration with institutional and organizational issues (Voegtlin et al., 2012). Although the extant research informs us about various isomorphic forces in general, there is a dire need to contextualize them. Are there certain isomorphic forces that present greater challenges than others for contemporary Indian business executives, and if so, what strategies do those executives use in response? To examine the institutional isomorphism responsible for ethical decision-making, we conducted in-depth interviews to understand Indian executives' experiences in ethical decision-making.

\section{Methods}

\section{Data Collection}

A semi-structured interview schedule was used for the data collection. The schedule was developed after extensive discussions between the researchers and was pilot tested with two senior executives employed in Indian MNCs. As suggested by Kvale (2007), the pretesting allowed the researchers to confirm the relevance and vocabulary equivalence of the questions for Indian business executives. Some minor modifications were made to the schedule, mainly for reasons of cultural sensitivity and vocabulary equivalence. Subsequently, 617 MNCs from 12 Indian cities (Ahmedabad, Aurangabad, Bengaluru, Bhavnagar, Chandigarh, Chennai, Hyderabad, Mumbai, Mysore, New Delhi, Pune and Vadodara) were purposively identified. Because there was no government or industry association published list of Indian MNCs available, we developed our own list. The identified firms were contacted via telephone and provided a briefing of the project aims and objectives. The liaison persons were tasked with 
identifying a potential interviewee, who had to be a member of the top management ream involved in decision-making related to organizational-level strategies (Nielsen and Nielsen, 2011). Sixty-four executives agreed to participate by the agreed deadline. We stopped after conducting 40 interviews, having reached theoretical saturation in which "no additional data are being found" (Glaser and Strauss, 2012, p.61).

Because of both the respondents' geographical spread and budget constraints, all interviews were conducted via telephone. The same schedule of questions (see Appendix) was utilized for all interviews. Given that the interview format was semi-structured, follow-up questions seeking further explanation, illustrations using anecdotal and/or experiential evidence and additional justifications were explored, depending on the initial response. This deliberate strategy of keeping the interview structure quite loose (i.e., open ended) resulted in unexpected and emergent themes. An experienced researcher with expertise in Indian national and business cultures conducted all the interviews. The interviewer applied Kvale's (1996) recommendations for a 'successful interviewer' while conducting the interviews. Some of the strategies included being well-informed about the interview themes, appropriate interview structure and interview etiquette, cultural sensitivity, open-mindedness and giving the interviewee opportunities to raise any issues or concerns. The interviews lasted between 75 and 90 minutes. To accommodate the executives' schedules, five of the interviews were conducted over two days. The participants gave consent to having the interviews recorded and transcribed verbatim. The transcripts were checked randomly for accuracy and completeness.

Table 1 about here

A summary of the interviewees' demographic details is presented in Table 2. The MNCs represented numerous business sectors, including automotive, banking, business service 
consulting, education, fast-moving consumer goods, healthcare, information technology, manufacturing, media, mining, petroleum and pharmaceuticals. The interviewees were part of the top management teams in their MNCs and were in-charge of firm-level strategic decisionmaking. Seventy percent of the interviewees were male. Sixty-five percent were over 40 years of age. All participants had at least an undergraduate degree, with 28 of the respondents having a masters' degree. Three participants had a doctorate. Twenty percent of the respondents had completed a degree or some part of their education overseas, and more than 50 percent of the respondents had overseas working experience. The average position tenure and industry tenure of the respondents were more than 9 years and more than 19 years, respectively.

Table 2 about here

\section{Social Desirability Bias}

Both qualitative studies employing the interview technique and studies attempting to understand ethical issues can elicit social desirability (Brunk, 2010; Nederhof, 1985). In addition, social desirability may be prominent in collectivistic societies such as India, where conformity to social norms and conventions is expected (Roberson and Fadil, 1999). Our study adopted seven strategies to minimize social desirability bias. First, we ensured that participating firms and executives volunteered to participate in our study. It was clearly communicated to the consenting firms and participants that they were free to withdraw at any stage of the research. Second, the identities of the participating firms and executives were kept anonymous. Third, in accordance with Kvale (2007), advice on the appropriateness and sensitivity of the draft interview questions was sought from a 'Committee of Experts' (involving two Indian executives). The advice we received was integrated into the final interview schedule. Fourth, at the outset, only a brief of the research study was provided to 
participating firms and executives. That brief included a short overview of the study and did not detail its subject matter. Steenkamp, de Jong and Baumgartner (2009, pp. 1-2) explained that this strategy assists in avoiding "priming respondents to answer in particular socially acceptable ways but creates scope to explore their values and priorities unfettered, before homing in on the main topic of interest." A fifth strategy involved employing an experienced interviewer to conduct the interviews using Kvale's (1996) strategies of a successful reviewer. Also, following Nederhof's (1985) suggestion, no power relationship existed between the interviewer and executives. Our sixth strategy followed Brunk's (2010) approach of conducting one-on-one interviews in familiar and comfortable surroundings to reduce social desirability bias. Finally, before the interviews began, we informed the executives that there was no right or wrong answers and probed for personal anecdotal evidence. In addition, we verified the executives' comments about their firms' codes of ethics using publicly available information. The combination of these strategies provide us with confidence that we have minimized social desirability bias.

\section{Data Analysis and Interpretation}

The interview data were systematically analyzed using NVivo, which provided more rigor in analyzing the data (Lindsay, 2004; Richards, 1999). This formalized software can help with the analysis, the interpretation of qualitative data and the development of new conceptual insights and themes (Welch, Welch and Tahvanainen, 2008; Buckley and Chapman, 1997). The data inputted into NVivo were analyzed using open and axial coding processes (Strauss and Corbin, 1997). Under the open coding process, which entails breaking down the data to compare, conceptualize and categorize it, the researchers highlighted and restated terms/phrases/sentences (Boeije, 2010; Chesler, 1987). The key phrases were termed concepts. Pursuant to this approach, similar concepts were grouped together as categories, which were 
then labeled (Strauss and Corbin, 1997). Using a constant comparative method of analysis (Silverman, 2000), a non-linear process was adopted to reduce the number of categories from concepts and the coding process oscillated between and within the concepts and categories.

The two researchers independently coded the data input into NVivo. After the first round of coding, we discussed the similarities and differences in the codes, groupings, concepts and categories. We also utilized the relevant literature to identify emergent concepts and categories, which was in line with Silverman's (2000) constant comparative method used to validate their reliability. This allowed the researchers to maximize inter-rater reliability (Frankfort-Nachmias and Nachmias, 1996). Miles and Huberman (1994) acknowledged that coder bias could be reduced through the use of multiple independent coders. The concepts and categories were confirmed after ongoing discussion between the two coders until a consensus was reached, providing 100 percent inter-rater reliability (Miles and Huberman, 1994). Table 3 illustrates the open coding procedure.

Table 3 about here

Pursuant to the open coding process, six categories were developed following the axial coding process (Strauss and Corbin, 1990, p.96) in which data "were put back together... by making connections between categories." The six categories included environmental context, institutional-level challenges, managerial-level challenges, institutional-level strategies, managerial-level strategies and ethical decision-making. Although ethical decision-making is presented as a unique category, it was related to the other categories using Strauss and Corbin's (1997) Paradigm Model, in which researchers established linkages based on the relationships between the categories, as outlined in Figure 1. Given the extensive volume of quotations obtained from the participants, the paper presents a summary of the categories in the following 
section via the liberal use of quotations, which are representative of the views expressed by the participants in the sample.

Figure 1 about here

\section{Results}

\section{Environmental Context}

$\mathrm{Li}$, Yao and Ahlstrom (2015) argue that there is often a lack of formal institutions in emerging economies, thus compelling decision makers to resort to whatever means are available to accomplish their tasks. Cordeiro et al. (in press) echo Li et al.'s (2015) findings by claiming that India still has a long road ahead in terms of improving governance and filling institutional voids. Thus, ethical decision-making requires contextual relevance. For that reason, we begin by identifying the factors that make India's business environment and ethics unique.

\section{Unique customs and values}

A holistic approach to management seems to be a unique feature of Indian businesses, which corresponds to studies by Chattopadhyay (2012) and Mulla and Krishnan (2014). In addition to a strong work ethic (espoused by three executives, E2, E6 and E26, all of whom mentioned working beyond their normal office hours to meet their clients' needs), there was a host of other approaches such as relationship building, gift-giving, and cultural ceremonies. These activities suggest that the Indian business environment is relationship oriented. Within this context, some executives expound the incorporation of religious values into the organization to facilitate greater humane interaction. These unique customs and values are illustrated in the following quotes:

In India, the values are strong because of the human touch, which is absent in 
overseas businesses. Overseas - they are very blunt and they can ask the company to leave the country overnight and once they leave, they have no relationship with them whereas in India, we still maintain the relationship. For example, I left my previous company in 2005, but I am still part of the company for any programs and cultural events and even something like membership and then we all meet and go out with families. E3

India is really a melting pot of different ethnicities and religions so it is difficult to say that there is one business ethics style in India. Indian businesses pride on Indian-ness. Maybe that's what is unique. We spend lot of time on religious ceremonies and cultural things, gift giving, dinners and lunches, social events etc. This was absent in the IT firm in London - there it was all down to money making and less time for socializing and events etc. So maybe that's unique to India. E38

\section{People-centric strategy}

Another theme that emerged is the attention that Indian MNCs give to their key stakeholders.

For instance, the executives explained that emotional attachment to their work was considered critical, to the extent that even during difficult times, organizations were reluctant to dismiss their employees. One executive attributed this humanistic approach to the perceived loyalty displayed by his organization's employees. Additionally, a harmonious connection with customers and suppliers is maintained such that problems are resolved personally rather than through the legal system. These positive approaches reflect the attention that leaders and management devote to balancing the competing demands of their stakeholders (Trotter, Day and Love, 1989). These views are expressed in the following statements:

Indian businesses focus on people. In my organization, we have a human centric strategy, which also applies to ethics. We make sure that everyone fully appreciates the ethical values of our organization and provide training. E33

One thing which I observed is that there are lots of emotional attachments with employees in the Indian businesses, which is normally not followed in foreign companies, and if the business is in loss (in India) they don't even think about letting employees go even in recession as they expect conditions to improve in due course. E11

\section{Lack of system - governance, education, accountability}


The executives reflected on why there was a general perception of widespread corruption and bribery in India. The responses included criticisms of the complexity of the business environment and a lack of governance in organizations and the government, which encouraged individuals and government departments to take advantage of their positions to demand token payments in the transactions and approval process. Executives also blamed the combination of widespread poverty and illiteracy, along with the lack of a system of accountability for perceived unethical practices. The comments suggest an externalization of ethical challenges, with no admission that businesses are to blame. Nevertheless, taken together, the lack of an ethics enabling system is very troubling (Chakraborty, 1997; Luo, 2005; Trotter et al., 1989). These observations are captured in the following quotes:

If you want something cleared from so many departments, for example, you installed a new plant then there is need of power and fire safety. We go to the government saying that we want to start the plant and so please give us the clearances. They will come and find some fault but there are no faults and in a way they say that you give us some money, then we will clear. Your and your company's ethics say not to give, so it takes time as you write to them. You write to their seniors. I mean you get the clearance but it has delayed the project. E3

Not only poverty but illiteracy is also a factor. This illiteracy is a menace to society from an ethics point of view as it clearly contributes towards ethical challenges. E30

Moreover, I would say there are also issues about accountability of systems in India. Lack of transparency and governance is giving India a bad name as far as ethics is concerned. E34

\section{Spiritual society}

Religiosity and spiritual consciousness featured prominently in the Indian business culture (Ananthram and Chan, 2016; Önal, 2010). Several executives mentioned that their religious faith and spirituality kept them mindful of ethical issues. Two executives brought up the concept of Sanatana Dharma, which refers to the 'eternal religion,' or Hinduism. In addition to Hinduism, other religions (such as Islam, Christianity, Sikhism, Jainism and Zoroastrianism) 
play important roles in the lives of numerous Indians and Indian society (Chan and Ananthram, 2017). This concept forms the ethos of Indian businesses and touches on what it means to live in a free society. These comments suggest that spirituality plays a prominent role in Indian businesses, as captured by the following quotes:

The spirituality or the Sanatana Dharma makes the Indian business ethics unique, which is coming from the Vedas. In Indian business there is uniqueness because of the Sanatana Dharma, through which only the legislations have come. E1

In my opinion, a country's ethics is developed to some extent on account of its culture - it's the same in India. And this culture enters corporations - for example, my corporation has an ethical code of conduct which is reflective of the ethics, values and morals of Indian culture as a whole. What I am trying to say is that business ethics like culture is different in different countries and contexts. E26

\section{Challenges at the Institutional Level}

The executives identified institutional-level challenges. The relevant responses were grouped as regulative, normative and cognitive challenges under the wider institutional-level challenges.

\section{Regulative challenges}

Numerous executives blamed the government for the lack of a regulatory structure that would curb unethical behavior. Given that clearances such as health and safety permits must be obtained from the government, there is a potential for government officials to act unethically when there seems to be no recourse to resolve an issue. Another source of frustration comes from the experiences of a slow legal system, which might lead unethical individuals to believe that they will never be caught or feed the perception that the bribes they receive outweigh any penalty they might be assessed. These findings respond to Treviño et al.'s (2006, p. 978) call for researchers to "explain how corruption becomes institutionalized in an organizational 
environment or beyond, in industries or even in countries." Some of these pent-up frustrations

with India's institutionalized corruption are expressed in the following quotes:

This is because of the political system of our country and the people who are involved in this political system actually have enabled this mess. So the policies are good but the people who are running the politics is a concerned area. The salary level of government employees is much lower when we compare to a corporate or other factors. So this is maybe a reason for government officials to take a short cut and where we end up having a corruption and whatever may you call it. E4

This is our legacy from the 'licence raj' [elaborate system of licenses, regulations and accompanying red tape] era, where it was a closed economy, where bribes were the only way to get anything done. This is true to a fair extent even today. The 'babu' mentality [red tape and bureaucracy promulgated by employees (babu)] is the biggest problem we have in India. The regulatory environment even today is morally corrupt because of this. Rampant corruption, bribe taking is sort of a given in certain industries especially public sectors because of these incompetent babus. E37

\section{Normative challenges}

In terms of normative challenges, cultural factors were a common denominator. For example, the widespread practice of corruption was seen as a challenge not only within various levels of the government but also within organizations that condone it. Several executives mentioned the challenge of remaining ethical within an unethical system. The high level of complexity in the government-business interface, coupled with a lax regard for ethics, has been argued to encourage unethical behaviors to circumvent the system (Collins et al., 2008). Another executive (E9) mentioned the inculcation of unethical behavior from childhood via parents bribing their children to elicit desirable behaviors, leading to an expectation in adulthood that ethics are negotiable. These views highlight the isomorphic force from the government and suggest that the family unit can also play an isomorphic role, as eloquently expressed in the following testimonies:

In India it's difficult because the system is different. I left the job only because of Indian ethics. I joined a government company after the completion of my MBA. In the government department everything can be bought and people can be sold. So doing business unethically is very easy over here. Secondly, over here the IAS 
(Indian Administration Service) and other high officers are not corrupted but the lower level officers (that are the clerks) are corrupt. These clerks bring the papers and the officers, without applying their mind, simply sign such papers. Without looking at the instruction, they just give approval. Whether the thing is in interest of the country or not, they don't care. E2

It is not only in government or private (sector) but it is always in every stage where I would rather say that we also corrupt our own children by giving them some kind of bribe, not to see TV or to go to school. We bribe them by giving chocolates or giving some kind of things like, we allow them to see TV. So it's in our culture where we have to change ourselves. E9

\section{Cognitive challenges}

Cognitive challenges refer to inertia of the will to improve the system. This inertia might be attributable to the difficulty associated with 'going against the grain.' Organizational and governmental leaders' lack of willingness to challenge the status quo was also identified as a problem (Collins et al., 2008; Pinto, Leana and Pil, 2008). These findings suggest that cognitive barriers overwhelmed individuals who have the goodwill and the desire to be ethical. Accordingly, it is often easier to just go along with unethical practices instead of fighting them. The following quotes allude to this inertia:

In every level there is an obstacle. There is something called herd mentality. Everybody is going in a particular direction and you will also be forced to go in that direction. E1

No one wants to take the bull by its horns. By that I mean influential government and business people do not want to remedy the situation. There is this attitude of "chaltha hai" - meaning "it is fine" and "let's deal with it". If these capable powerful people cannot do anything to solve the ethical problems, then how can the common employee or common man [sic] do anything? In India, bottom-up strategy or initiative does not work. E32

\section{Challenges at the Managerial Level}

The executives also identified challenges at the managerial level that emphasized leadership issues, a lack of prudent HR measures and unethical values as a result of the presence of greed and corruption. 


\section{Lack of leadership}

Several executives acknowledged that leaders' failure to support ethical behavior was a major factor in their complacency. Individuals with the goodwill, intention and desire to improve the ethical climate of their organizations are likely to meet obstacles when there is a lack of leadership support (Zhu, Sun and Leung, 2014). This challenge is compounded by the hierarchical nature of Indian society (Hofstede, 2013), which makes it difficult to challenge offending authorities. Acknowledgements of these issues are captured in the following statements:

At the managerial level it's the same obstacle and that is what I am saying that in day-to-day life, because he [sic] has to compromise always many times due to his [sic] ethics, because there are some disturbances in this work, because if he [sic] has fixed mindset that $\mathrm{I}$ have to do this in this way, but maybe his [sic] boss or his [sic] higher authority, may not be willing to do that. E6

If the top person is ethical, he [sic] will ask everyone to follow that. If you have pressure from the top, you have to either save your job or work peacefully. You have to actually abide by the instructions coming from the top. E17

\section{Lack of prudent HR measures}

Human resource (HR) policies and practices that inculcate an ethical climate are necessary to combat unethical behavior (Argandoña, 2003; Beeri, Dayan, Vigoda-Gadot and Werner, 2013). Two critical areas in HR were identified by two executives as potential problem areas. First, the lack of thoroughness and transparency in the recruitment and selection process meant that the best and most competent candidate might not be chosen. Second, the lack of role clarity suggested that some individuals might be unaware both of the limits of their roles and obligations and of ethical boundaries. However, initiatives to enact positive changes were thwarted by apathy within the HR department. These concerns are expressed in the following statements:

I think the challenges are more for HR people to find the right candidate, right people and that is a big challenge because in our country, transparency is an issue 
and not every candidate or every employer or the recruiter is so transparent that we know their backgrounds. E4

Biggest challenge for HR is that it needs to play a more important role in ethics. I have read a lot about how HR can assist in the overall ethical practices of the organization - right hiring process, ongoing training, ensuring transparency and fairness in everything from hiring to firing to redundancy, managing complaints on harassment and other aspects. E35

\section{Unethical value system}

The overwhelming presence of unethical values within the system, shaped by greed and corruption, seemed to be inculcating unethical behaviors (Chakraborty, 1997; Li et al., 2015). At times, some of the executives were caught in a situation in which they could either go along with an unethical practice or lose their jobs simply by holding firm to ethical principles. There might also be individuals who, through their personal circumstances, engage in unethical behavior when the opportunity arises and there are no checks and balances in the system. At this juncture, it would be interesting to contrast these observations with the spiritual society that the executives claimed makes Indian businesses unique. One reason for this contradiction might be that individual values are more deeply entrenched than spiritual values. These concerns are captured in the following quotes:

I think an individual manager's value system is important. Each manager is unique and has his or her own values that have taken long time to shape. When one's value system dictates that it is above the law, that individual will then engage in illegal unethical activities. So dishonesty and corruption become part of the person's value. This is a huge challenge mainly in developing countries like India. E39

If a person comes from poor background and he [sic] is the only bread earner, one person earning and ten are having food it will not be sufficient so he [sic] is forced to go in a wrong group to earn money. Many organizations hire their own people at the management level. E15 


\section{Strategies at the Institutional Level}

After the executives mentioned the challenges that they faced, they were asked to reflect on the strategies that they employed to resolve those problems at the institutional level. The quotations were coded under the themes of regulative, normative and cognitive strategies.

\section{Regulative strategies}

One of the steps that has been undertaken by some executives to promote ethical behaviors in their organizations centers around the implementation of an ethical code of conduct, which includes a whistle-blower policy and protocols for dealing with stakeholders. Central to the success of this implementation process is ensuring that the code and expectations are being communicated to everybody, that they are followed and that there is zero tolerance for unethical practices. Organizational leaders were required to set ethical examples to create an ethical climate within their organizations (Beeri et al., 2013; Treviño et al., 2006). Although a code, policies and process may be in place, leaders are charged with enforcing them, at times rendering these strategies fragile. These views are advocated in the following quotes:

We have got various purchase policies; various Central Vigilance Commission (CVC) guidelines, audit and all these things to ensure that at least primarily the basic ethical practices are maintained. These guidelines define the number of vendors, the number of vendors to quote, kinds of tenders to be quoted at different price levels and the requisite systems to be practiced before selecting the vendor. Even for taking something in return, say gifts as well during any occasion or festival, there are guidelines for the things that you want to gift. E5

I think as a first step, announce very hard measures for anyone, whether it is at the government level or an individual level or at a business level. A swift and hard punishment for those who resort to unethical practices is a first step but then you have, overall, the judiciary who will do things swiftly and not 10-20 years so this has to go hand-in-hand. We have something known as employee forums wherein we have whistle blower's policy. We have lot of policies which can help them in taking out to various people in the hierarchy without knowing that who has tried to reach them out. E10

Next, transparency in business operations is believed to facilitate ethical behavior (Beeri et al., 
2013). Three executives spoke about three stakeholders (customers, government and financial institutions) for whom transparency was important. It is important for the various stakeholders to understand the organization's position in terms of ethics $(\mathrm{Wu}, 2009)$. Ethical processes should be followed and when there is an anomaly, a corrective action should be triggered to remedy the situation. These outlooks are expressed in the following quotes:

In my business, we need to adhere to the documentation policies laid down by the regulatory bodies. Even if somebody would want to see the documentation, it is possible. So we have various measures or checkpoints and we ensure that the documentation which we get from the customer is correct and if the documentation is not complete, it is not processed. E12

There is nothing hidden in between the lines and it is explained upfront to the customers. The customer is not duped by the company at all. If there is clarity in policies and transparency with financial institution or money lenders and customers, then the business can be ethical. E28

\section{Normative strategies}

To convey the seriousness of ethics, some executives have proposed training and learning from the experiences of others. Case studies during the training sessions involving the most senior to the lowest-level employees are utilized. Additionally, executives are encouraged to adopt various best practices from other countries to improve domestic ethical practices. Waples, Antes, Murphy, Connelly and Mumford (2009) find in a meta-analysis that such instructions have minimal impact and that attention should be given to complement case studies with other methods. These recommendations are included in the following quotes:

If an organization wants its executives to be ethical, then we have workshops where we conduct lectures and things by the vigilance department, where we have some case study about how by being unethical what has been the loss to the organization, how it has been bad for the person concerned, how it is affecting the morale of the other people because once you have one bad person within your group it immediately starts affecting the morale of the other colleagues also. E7

They should bring the best practices from abroad and try to help Indian government and businesses to implement those things. They should also participate into bringing more knowledge from their experience and they should impart it with [the] Indian public. And they should become part of all these education processes. E29 
We have certain norms within our multinational company regarding ethics. These norms are non-negotiable and they are reinforced through our actions on a day-today basis. It is mandatory for a company to be ethical to constantly benchmark its norms to the ones that are globally acceptable and constantly apply them. Every individual employee has to be on the same page regarding ethical norms, duties, expectations and be held accountable. Everyone needs to step up and want to be ethical. E36

\section{Cognitive strategies}

Numerous executives believed that it was possible to shape individuals' ethical behavior. First, it was important to understand the root cause(s) of unethical behavior (Li et al., 2015). Next, behavioral modification strategies, either through counseling (or training) or selfdetermination, could be applied (Lange, 2008). Nevertheless, regardless of the approach, an important feature that has appeared throughout the executives' comments is that success or failure seems to depend on the willpower of individuals and the collective cooperation of others. One executive acknowledged that it was difficult to get things done productively while being ethical but recounted the stellar examples of the Tata Group and Infosys (two notable Indian MNCs) for their apparent ability to engage in ethical business practices. These beliefs are derived from the following quotes:

It's very difficult to change the minds of the people, with organization, with the family and within the nation. But for all this you need a lot of determination. Either people will move with you or they will move you. One needs a strong will power to do so. This ethical practice can be implemented but it requires time. It requires patience and it requires strategy. You need to have a complete team who will agree with your thoughts. Without a team, you cannot do it. E2

If we put this [ethics] into practice, this would result in a lot of delays. I mean delays in clearances and things like that, which will then impact on our performance. But there are companies in India who practice ethical practices, extremely well and still performing, so everyone has to learn how to do this. TATAs are performing very well in India, so I keep asking myself that if TATAs can perform, if Infosys can perform, then why not us. E10

\section{Managerial-Level Strategies}


The managerial-level strategies explained by the executives were related to human resource management (HRM) practices, leadership support, acting as a role model for the rest of the organization, and the cultivation and development of an ethical mindset.

\section{HRM practices}

Several areas of HRM practices have the capacity to improve the ethical climate of organizations (Pinto et al., 2008; Wang and Hackett, 2016). The recruitment and selection process is identified as a vital area of focus. One executive mentioned the proper recruitment of applicants, including thorough screening, background checks and induction after the selection process. Another executive mentioned the importance of ensuring a good person-job fit and person-organization fit. Executives also noted that appropriate remuneration strategies were critical to ensure that individuals are fairly compensated (Beeri et al., 2013). Other areas where attention should be focused include job security and the existence of clearly written and communicated standard operating procedures. One recurring feature is that individuals throughout an organization are responsible for ensuring compliance. In this case, HRM can play a significant role by removing the incentive, to the greatest extent possible, for individuals to engage in unethical behaviors. These views are expressed below:

Multiple things, at the time of recruitment, proper screening, proper reference check, induction; when he [sic] is finally selected, proper induction, dissemination of code of conduct, meeting with new employees, finally code of conduct, making norms i.e., if you violate this code of conduct then what are the repercussions. E12

If you give them the job security and they have been paid proper compensation, I don't think so they will go in for unethical practices. E19

There is a written down standard operating procedure (SOP) for every project that we do. There is a SOP for everything, so there is no point that we can deviate from that SOP. E23

\section{Leadership and role models}


Having good leadership and being a good role model were both suggested as potent approaches to improve an organization's ethical climate (Beeri et al., 2013; Wang and Hackett, 2016).

Given that an organization's leadership sets most of the ethical tone, a leader is advised to remain impartial and empathetic and to be willing to mentor relatively junior colleagues or staff members. Additionally, wherever possible, it is recommended that the leader build up individuals' characters instead of using punitive measures as a first resort. Another important attribute of leaders is the humility to improve themselves as they lead others to become ethical. Dynamic interactions between an organization's leaders and employees toward a common good have transformative potential for all parties (Arjoon, 2000). These practices and suggestions are contained in the following quotes:

I have to practice first before I preach. That is what I have to personally ensure. E1

The department head has to follow ethical practices. He [sic] has to be very impartial. He [sic] has to showcase his [sic] leadership qualities not by pointing out mistakes in front of others. He [sic] should look to improve his [sic] level of thinking about his [sic] subordinates instead of insulting someone or being partial to someone. He [sic] should see as to what he [sic] can do to the person who is not doing things in right manner. Put it in a positive way. One-to-one feedback has to be given before taking any steps. E15

Every staff should have their mentor who should guide them what to do and what not to do so any organization. If they arrange some programs like these, definitely it will help organizations to grow faster than regular growth. E18

\section{Ethical mindset cultivation and development}

Since individuals at various levels can affect an organization's ethical climate, one theme that has emerged is the cultivation and development of a collective ethical mindset (Issa and Pick, 2010). A few executives mentioned the importance of awareness through continuous evidencebased training. Another executive suggested the use of a long-term development program to form the ethical mindset of the next generation of executives and employees. The concept of an "ethical soul" (E39) is particularly striking because it resonates with the idea that although 
ethical decision-making starts with individuals, the notion of ethics must be shared by all. Some studies (e.g., Driscoll and McKee, 2007; Mendonca, 2001) have also argued that an organization's soul is intrinsically linked to its leadership style and employees, which have the potential to promote or destroy it. These ideas are found in the following quotes:

There should be continuous training and awareness among the people with evidences. So I think, first, they should have to change the mindset of the employee. So encourage more ethical practice if there is a reward system. E6

It's important for every individual in the company to have a clear conscience, an ethical mindset. And it takes time for ethical mindset to be inculcated. So here the role of ethical mindset training is important. Companies that can take this seriously will ensure that the company as a whole possesses an ethical soul or mindset. And that is the best strategy for the company going forward with regards to ethics. E39

Corporations need to develop an ethical mindset and while [it is] challenging; investment and direction towards this will clearly go a long way in determining whether your corporation is morally sound or bankrupt. E40

\section{Discussion}

In response to Voegtlin et al.'s (2012) call for studies to incorporate the economic and moral aspects of globalization when studying ethical leadership, the overall aim of this study was to investigate the challenges faced and strategies utilized by executives in the ethical decisionmaking process in MNCs. We utilize neo-institutional theory to discern the various isomorphic forces that affect an organization's legitimacy. These forces present ethical challenges for the executives. In terms of coercive isomorphism, we observe that the political and legal institutions seem to be working antagonistically. Despite the existence of legal frameworks, India's bureaucracy, its highly politicized environment and its cumbersome legal system pose tremendous challenges to ethical decision-making (Cordeiro et al., in press). With mimetic isomorphism, instead of adopting 'best practices,' there is a general apathy toward business ethics. Specifically, many decision makers opt for the status quo because it is simply easier than fighting the system. The lack of visible ethics promotion by professional bodies is also a 
concern, which might explain the lack of transparency and haphazard HR practices, especially in the areas of recruitment and selection. Thus, weak institutions coupled with a general inertia to correct the status quo provide 'perfect storm' conditions in which unethical behaviors and practices thrive (Treviño et al., 2006).

Next we identify how the executives develop and implement strategies at the institutional and managerial levels to mitigate those ethical challenges. The solutions proposed by the executives, such as providing education and training in ethics, using ethical codes of conduct, encouraging transparency, conducting ethical audits, using behavior modification strategies, incorporating ethics into HRM practices, role modeling by leaders and cultivating an ethical mindset for individuals and organizations, hint at the prevalence of 'mimetic isomorphisms.' The extent to which these 'mimetic isomorphisms' are successful in encouraging ethical decision-making remain questionable, since corruption and briberies are still widespread (Li et al., 2015; Patel and Schaefer, 2009; Srinivasan, 2011). Interestingly, although the executives mentioned the existence of standard operating procedures, codes of ethics, compliance policies and guidelines, there is no evidence of 'normative isomorphism.' In fact, compliance with ethical standards seems to be organization-driven rather than stemming from any professional body. We discuss these findings (summarized in Figure 1) further while highlighting our theoretical and empirical contributions and provide implications for practice.

\section{Theoretical and Empirical Contributions}

We make two theoretical contributions. First, we extend neo-institutional theory to ethical decision-making by identifying the relevant institutional (regulative, normative and cognitive) and managerial-level challenges that confront executives in Indian MNCs. Moreover, we delineate the strategies employed by the executives to negotiate these challenges. We thus 
address the shortcomings identified by Nielsen and Massa (2013, p.136) who observed that neo-institutional theory "seldom explicitly considered ethics and the sustainability of ethical behavior as an end in itself." While these findings were based on data from Indian MNCs, we affirm that the role of contextually embedded environmental factors is critical and needs to be taken into consideration when studying ethical decision-making using neo-institutional theory as a lens. Thus, the factors that influence the business environment in a particular national context need to be understood, because they provide a foundation for the challenges and strategies of ethical decision-making.

Second, we theorize how the institutional and managerial levels combined contribute to ethical decision-making. At the institutional level, traditions and institutional forces have significant potential for corporate governance in eliciting ethical behavior and as such, they provide a foundation for the relevance of neo-institutional theory in synthesizing these behaviors. However, as our findings have shown, individual and organizational efforts are sometimes thwarted by a hierarchical political system with lax checks and balances. Such a system is conducive to unscrupulous behavior by government officials who expect and demand bribes to facilitate the approval of operational permits, thus creating both institutional and managerial challenges for organizations and their executives (Prashantham and Dhanaraj, 2015). Widespread poverty and illiteracy were also blamed for the prevalence of unethical practices, which suggests that there remains much to be improved on when it comes to the educational and social support systems. Resort to legal recourse, which is ipso facto slow, is uncommon, and executives and organizations are often at the mercy of corrupt government officials. One interesting discovery is that the family institution is considered an incubator for bribery where parents are blamed for bribing their children, thus inculcating a sense that everything (including ethics) is negotiable. Based on these observations, we contend that what India lacks is not simply an insufficient legal system for fighting unethical practices, but current 
socio-cultural and political forces paralyze good-willed individuals who are intent on cultivating an ethical environment both within businesses and in the business-government interface. Previous studies on neo-institutional theory generally treat the various isomorphic forces indiscriminately (DiMaggio and Powell, 1983; Suddaby et al., 2013), but our study finds that there are competing 'coercive isomorphic' forces at play, where political and socio-cultural forces displace legal forces when it comes to ethical decision-making in India.

At the managerial level, the culprits include the ad nauseam prevalence of unethical practices and conditions that encourage unethical individuals both within and outside of an organization to seize their opportunities and personally profit. Executives have the arduous task of improving their organization's ethical climate and should implement a zero-tolerance approach to bribery, corruption, nepotism, cronyism and other forms of unethical practices. Although it is convenient to blame some executives for the widespread unethical practices in their organizations, our study's findings also reveal that some executives are engaged in unethical behavior for the sake of personal gains or as a means of getting things accomplished e.g., ensuring that the organization obtains governmental approval for a health and safety permit even when there are no perceived problems. Thus, it is plausible that many key decision-makers will just go along with the herd mentality and bribe corrupt officials so that their businesses do not suffer from delays. There may also be well-intentioned executives who found themselves overwhelmed by the system, eventually giving in to the herd mentality. Another trigger stems from personal circumstances in which individuals from a poorer background and a large family might be tempted to make ends meet through unethical behaviors. At the crux of these various findings is the perception that the benefits derived from unethical behaviors are believed to outweigh the risks. These findings suggest that there is much room for improvement in making a coordinated effort to combat unethical behaviors within and without an organization's boundaries ('coercive isomorphisms'). In summary, our 
findings suggest that the institutional and managerial levels are not mutually exclusive and need to be studied together to navigate the complexities of ethical decision-making, because the various isomorphic forces affect an organization's legitimacy differently (Ahlstrom, Bruton, \& Yeh, 2008). An exception in our study is that normative isomorphism seems to be lacking. Consequently, ethical decision-making for MNCs should be viewed as a multi-level phenomenon.

We also make an empirical contribution in that our findings explicates the challenges faced by executives in ethical decision-making in the Indian MNCs' context. Indeed, the confluence of institutional and managerial challenges in India is driving executives to develop strategies to alleviate the identified challenges. Our model provides a rich understanding of the complicated nature of ethical decision-making. Notwithstanding contextual differences, the model can be applied to other emerging (e.g., Brazil and South Africa) and developing (e.g., Myanmar and Bangladesh) economic settings that face myriad institutional- and managerial-level issues related to ethical decision-making.

\section{Practical Contributions}

The findings also have several practical implications. There is an urgent need for corporate governance frameworks underpinned by the principles of accountability and transparency at the national, industry and organizational levels in India. Given that corporate governance differs across countries, it must be studied and implemented holistically by taking institutional nuances into consideration (Filatotchev, Jackson and Nakajima, 2013; Rejchrt and Higgs, 2015). Moreover, it is incumbent that institutional actors seriously promote ethical standards of behavior so that ethics become a norm both in Indian government agencies, businesses and in the business-government interface (Nair et al., 2015). Additionally, educational institutions and professional bodies in India should consider more intensely incorporating business and 
professional ethics into various occupational groups, thus promoting the normative isomorphism that was lacking in our findings. Indeed, initiatives to promote ethical practices can only work when they are enforced and implemented.

There is a general belief that a humanistic approach to management is prevalent in India, which stems from the country's unique customs and values. Thus, maintaining cordial relationships including with those in previous firms, reliance on faith, trust and openness, connectedness to stakeholders and being respectful regardless of organizational rank were considered critical. These observations indicate a concern for others and extend beyond a transactional approach to doing business. This uniqueness was attributed both to religious pluralism in India, where various forms of virtues are shared, and to integrated signaling that religious and cultural institutions play important roles in the Indian business context.

Our findings also shed light on the important role of family and socio-cultural institutions in cultivating ethical norms from a young age. Executives seemed to bring their morality-related experiences from childhood and beyond into the workplace as part of their socio-cultural baggage. One suggestion is to instill ethical virtues based on religiosity and spirituality in family situations, which have been shown to align with organizational ethical virtues within the workplace and thus to assist in ethical decision-making in multi-faith societies (Ananthram and Chan, 2016). Furthermore, both families and educational institutions are encouraged to pay more attention to moral issues to develop the next generation of morally upright executives leading MNCs.

Executives must relentlessly hold themselves and others to higher ethical standards. At the institutional level, executives should be personally involved in the creation and communication of organizational codes of conduct, which should not only contain protocols for interactions with stakeholders but also outline the consequences of unethical practices. Ethical awareness should also be part of an organization's training and development program, 
recruitment and selection process, remuneration, induction program, mentoring program, and disciplinary and termination processes (Agrawal, 2017; Srinivasan, 2011). At this juncture, it would be useful for executives to consider and adopt their industries' best practices from India and abroad. Concepts of virtue ethics that are indigenous to the Indian psyche should also be incorporated into various initiatives (Ananthram and Chan, 2016). One executive (E23) mentioned his attempt to remain ethical at the risk of losing business and his disgruntled clients eventually returned. Therefore, it is useful to facilitate 'mimetic isomorphism' so that procedures and practices that encourage ethical behavior can be shared and learned. In addition, Indian executives, and by extension other executives, are encouraged to heed the call by Mahatma Gandhi, who stated that 'It's the action, not the fruit of the action, that's important. You have to do the right thing. It may not be in your power, may not be in your time, that there'll be any fruit. But that doesn't mean you stop doing the right thing. You may never know what results come from your action. But if you do nothing, there will be no result" (Stone, 2001, p.175).

Finally, our results highlight the importance of HR and leadership in negotiating the identified challenges at the managerial level. HR should design and implement recruitment strategies that involve screening executives for ethical virtues and associated competencies. To ensure that individual ethical virtues are aligned with corporate goals, ideals and ethical pursuits, it is also of paramount importance to provide ongoing ethical training (Agarawal, 2017). Leaders are also encouraged to act as role models and lead by example by demonstrating a zero-tolerance policy for ethical transgressions. Moreover, both executives and HR departments are encouraged to develop measures to cultivate an ethical mindset. 


\section{Limitations and Suggestions for Future Research}

The limitations of this study should be taken into consideration and could serve as opportunities for future research. Although this study has peered into executives' ethical decision-making process, future research could examine how individual background differences (such as gender, age, educational background and level, organizational levels and organizational tenure) might influence this process in Indian businesses. Additionally, given that our study found several accounts of unethical practices at various levels of business and the government, future studies could attempt to study these phenomena to explicate the ethical challenges and considerations in the business-government interface and further contribute to extant knowledge.

Furthermore, given the sensitivity of exploring ethical decision-making at a personal level, there might be a certain degree of impression management and social desirability on the part of the executives that cannot be ruled out. Therefore, extreme care should be exercised in the framing of interview questions, and we propose that researchers should ask about (un)ethical practices indirectly first (i.e., knowledge about (un)ethical practices in other departments, state and organizations) before proceeding to direct questions, as we took great lengths to do in our study. Our strategies to address both social desirability and the candidness of the executives in our sample in discussing unethical practices gave us confidence that the problem of social desirability was minimal, if not non-existent.

Although we find it laudable that there are two successful cases of individual executives 'sticking to their guns' (E2 and E3) as far as ethical behavior is concerned, we suspect that these are positive anomalies and warrant further exploration. In our study, one executive (E3) managed to find a reasonable government official higher up in the hierarchy to approve his plan, but what would happen if there were continuous roadblocks along the way? Additionally, how would the government deal with officials who mishandled cases? In another case, an executive (E2) left his job rather than engage in unethical behavior. 
Moreover, institutional isomorphism might be different across national and cultural boundaries. Thus, future research could examine ethical decision-making and the leader's role in other contexts, particularly in other emerging economies (Wang, Ahlstrom, Nair, \& Hang, 2008). Future studies could also consider effective changes in 'coercive isomorphism,' 'mimetic isomorphism' and 'normative isomorphism' that help facilitate ethical decisionmaking, especially when there is a change from a weak to a strong isomorphism.

\section{Conclusion}

Our study provides new insights into the ethical decision-making process based on interviews with 40 executives from Indian MNCs that were purposively identified. Through the lens of neo-institutional theory, we find that India's socio-cultural and political institutions exert the most influence on unethical behavior. Although the continuing unethical practices in Indian MNCs and government agencies remain disconcerting, some of the suggested strategies at the institutional and managerial levels appear to be effective in offsetting these problems. Our findings have provided optimism that ethical decision-making is achievable through a supportive institutional environment, an unequivocal subscription to ethical principles, an effective implementation of ethical standards of behavior and the cultivation of an ethical mindset. These findings extend neo-institutional theory to ethical decision-making and provide underpinning to the importance of combining institutional and managerial levels when studying this complex phenomenon. Executives are encouraged to strengthen the corporate governance frameworks within MNCs, provide strong and unwavering ethical leadership and also understand the impact of family and socio-cultural institutions that shape individuals' ethical preferences. Our findings are proffered as a multi-level theoretical model of ethical decision-making for further validation and extension as we make a strong case for extending this stream of research. 


\section{References}

Aßländer, M. S., Roloff, J., \& Nayir, D. Z. 2016. Suppliers as stewards?: Managing social standards in first- and second-tier suppliers. Journal of Business Ethics, 139(4): 661-683.

A $\beta$ länder, M. S. 2011. Corporate social responsibility as subsidiary co-responsibility: A macroeconomic perspective. Journal of Business Ethics, 99(1): 115-128.

Agrawal, R. K. 2017. Do ethical climates impact trust in management?: A study in Indian context. International Journal of Organizational Analysis, 25(5): 804-824.

Ahlstrom, D., Bruton, G. D., \& Yeh, K. S. 2008. Private firms in China: Building legitimacy in an emerging economy. Journal of World Business, 43(4): 385-399.

Al-Khatib, J. A., Rawwas, M. Y. A., \& Vitell, S. J. 2004. Organizational ethics in developing countries: A comparative analysis. Journal of Business Ethics, 55(4): 309-322.

Ananthram, S., \& Chan, C. 2016. Religiosity, spirituality and ethical behavior: Perspectives from some executives in Indian multinational enterprises. Asia Pacific Journal of Management, 33(3): 843-880.

Ardichvili, A., Jondle, D., Kowske, B., Cornachione, E., Li, J., \& Thakadipuram, T. 2012. Ethical cultures in large business organizations in Brazil, Russia, India, and China. Journal of Business Ethics, 105(4): 415-428.

Argandoña, A. 2003. Fostering values in organizations. Journal of Business Ethics, 45(1-2): 15-28.

Arjoon, S. 2000. Virtue theory as a dynamic theory of business. Journal of Business Ethics, 28(2): 159-178.

Ashwin, A. S., Krishnan, R. T., \& George, R. 2015. Family firms in India: Family involvement, innovation and agency and stewardship behaviors. Asia Pacific Journal of Management, 32(4): 869-900.

Balakrishnan, J., Malhotra, A., \& Falkenberg, L. 2017. Multi-level corporate responsibility: A comparison of Gandhi's trusteeship with stakeholder and stewardship frameworks. Journal of Business Ethics, 141(1): 133-150.

Beddewela, E., \& Fairbrass. J. 2016. Seeking legitimacy through CSR: Institutional pressures and corporate responses of multinationals in Sri Lanka. Journal of Business Ethics, 136(3): 503-522.

Beekun, R. I., Stedham, Y., Westerman, J. W., \& Yamamura, J. H. 2010. Effects of justice and utilitarianism on ethical decision making: A cross-cultural examination of tender similarities and differences. Business Ethics: A European Review, 19(4): 309-325.

Beeri, I., Dayan, R., Vigoda-Gadot, E., \& Werner, S. B. 2013. Advancing ethics in public organizations: The impact of an ethics program on employees' perceptions and behaviors in a regional council. Journal of Business Ethics, 112(1): 59-78.

Berger, R., \& Herstein, R. 2014. The evolution of business ethics in India. International Journal of Social Economics, 41(11): 1073-1086.

Bhowmik, S. K. 2009. Labor sociology searching for a direction. Work and Occupations, 36(2): 126-144.

Björkman, I., Fey, C., \& Park, H. 2007. Institutional theory and MNC subsidiaries HRM practices: Evidence from a three-country study. Journal of International Business Studies, 38(3): 430-446.

Boeije, H. 2010. Analysis in qualitative research. London: Sage.

Borowski, S. C., \& Ugras, Y. J. 1998. Business students and ethics: A meta-analysis. Journal of Business Ethics, 17(11): 1117-1127. 
Brown, M. E., \& Mitchell, M. S. 2010. Ethical and unethical leadership: Exploring new avenues for future research. Business Ethics Quarterly, 20(4): 583-616.

Brunk, K. H. 2010. Exploring origins of ethical company/brand perceptions - A consumer perspective of corporate ethics. Journal of Business Ethics, 63(3): 255-262.

Buckley, M. 2013. A constructivist approach to business ethics. Journal of Business Ethics, 117(4): 695-706.

Buckley, P. J., \& Chapman, M. 1997. A longitudinal study of the internationalisation process in a small sample of pharmaceutical and scientific instrument companies. Journal of Marketing Management, 13(1-3): 43-55.

Chakraborthy, S. K. 1997. Business ethics in India. Journal of Business Ethics, 16(14): 15291538.

Chattopadhyay, C. 2012. Indian philosophy and business ethics: A review. Advances in Management \& Applied Economics, 2(3): 111-123.

Chan, C., \& Ananthram, S. 2017. Religion-based decision making in Indian multinationals: A multi-faith study of ethical virtues and mindsets. Journal of Business Ethics (forthcoming)

Chan-Serafin, S., Brief, A. P., \& George, J. M. 2014. How does religion matter and why?: Religion and the organizational sciences. Organization Science, 24(5): 1585-1600.

Chesler, M. 1987. Professionals' views of the 'dangers' of self-help groups, Ann Arbor: Centre for Research on Social Organization, Working Paper Series, University of Michigan.

Cleveland, M., Favo, C. M., Frecka, T. J., \& Owens, C. L. 2009. Trends in the international fight against bribery and corruption. Journal of Business Ethics, 90(2): 199-244.

Collins, J. D., Uhlenbruck, K., \& Rodriguez, P. 2008. Why firms engage in corruption: A top management perspective. Journal of Business Ethics, 87(1): 89-108.

Conroy, S. J., \& Emerson, T. L. N. 2004. Business education and religion: Religiosity as a predictor of ethical awareness among students. Journal of Business Ethics, 50(4): 383-396.

Cooke, F. L., \& Saini, D. S. 2015. From legalism to strategic HRM in India?: Grievance management in transition. Asia Pacific Journal of Management, 32(3): 619-643.

Cordeiro, J. J., Galeazzo, A., Shaw, T. S., Veliyath, R., \& Nandakumar, M. K. in press. Ownership influences on corporate social responsibility in the Indian context. Asia Pacific Journal of Management,

Crilly, D., Schneider, S. C., \& Zollo, M. 2011. Psychological antecedents to socially responsible behavior. European Management Review, 5(3): 175-190.

Crossan, M., Mazutis, D., \& Seikts, G. 2013. In search of virtue: The role of virtues, values and character strengths in ethical decision making. Journal of Business Ethics, 113(4): 567571.

Derry, R. 1989. An empirical study of moral reasoning. Journal of Business Ethics, 8(11): 855862.

DiMaggio, P. J., \& Powell, W. W. 1983. The iron cage revisited: Institutional isomorphism and collective rationality in organizational fields. American Sociological Review, 48(2): 147-160.

DiMaggio, P. J., \& Powell, W. W. 1991. The new institutionalism in organizational analysis. Chicago, IL: University of Chicago Press.

Driscoll, C. \& McKee, M. 2007. Restorying a culture of ethical and spiritual values: A role for leader storytelling. Journal of Business Ethics, 73(2): 205-217.

Egri, C. P., \& Herman, S. 2000. Leadership in the North American environmental sector: Values, leadership styles, and contexts of environmental leaders and their organizations. Academy of Management Journal, 43(4): 571-604.

Fernando, A. C. 2009. Business ethics: An Indian perspective. New Delhi, India: Dorling Kindersley. 
Filatotchev, I., Jackson, G., \& Nakajima, C. 2013. Corporate governance and national institutions: A review and emerging research agenda. Asia Pacific Journal of Management, 30(4): 965-986.

Frankfort-Nachmias, C., \& Nachmias, D. 1996. Research methods in the social sciences. New York, NY: St. Martin's Press.

Fyke, J. P., \& Buzzanell, P. M. 2013. The ethics of conscious capitalism: Wicked problems in leading change and changing leaders. Human Relations, 66(12): 1619-1643.

Glaser, B. G., \& Strauss, A. L. 2012. The discovery of grounded theory: Strategies for qualitative research. Piscataway, NJ: Aldine Transaction.

Grojean, M. W., Resick, C. J., Dickson, M. W., \& Smith, D. B. 2004. Leaders, values, and organizational climate: Examining leadership strategies for establishing an organizational climate regarding ethics. Journal of Business Ethics, 55(3): 223-241.

Hartman, E. M. 1998. The role of character in business ethics. Business Ethics Quarterly, 8(3): 547-559.

Hearn, B. 2015. Institutional influences on board composition of international joint venture firms listing on emerging stock exchanges: Evidence from Africa. Journal of World Business, 50(1): 205-219.

Hofstede, G. 2013. Hierarchical power distance in forty countries. In C. J. Lammers \& D. J. Hickson (Eds.), Organizations alike and unlike: International and interinstitutional studies in the sociology of organizations: 97-119. New York, NY: Routledge.

Issa, T., \& Pick, D. 2010. Ethical mindsets: An Australian study. Journal of Business Ethics, 96(4): 613-629.

Kalshoven, K., Den Hartog, D. N., \& Hoogh, A. H. B. 2011. Ethical leader behavior and big five factors of personality. Journal of Business Ethics, 100(2): 349-366.

Kohls, J., \& Buller, P. 1994. Resolving cross-cultural ethical conflict: Exploring alternative strategies. Journal of Business Ethics, 13(1): 31-38.

Kuntz, J. R. C., Kuntz, J. R., Elenkov, D., \& Nabirukhina, A. 2013. Characterizing ethical cases: A cross-cultural investigation of individual differences, organizational climate, and leadership on ethical decision-making. Journal of Business Ethics, 113(2): 317-331.

Kvale, S. 1996. InterViews: An introduction to qualitative research interviewing. Thousand Oaks, CA: Sage.

Kvale, S. 2007. Doing interviews. Thousand Oaks, CA: Sage.

Lange, D. 2008. A multidimensional conceptualization of organizational corruption control. Academy of Management Review, 33(3): 710-729.

Li, Y., Chun, H., Ashkanasy, N. M., \& Ahlstrom, D. 2012. A multi-level study of emergent group leadership: Effects of emotional stability and group conflict. Asia Pacific Journal of Management, 29(2): 351-366.

Li, Y., Yao, F. K., \& Ahlstrom, D. 2015. The social dilemma of bribery in emerging economies: A dynamic model of emotion, social value, and institutional uncertainty. Asia Pacific Journal of Management, 32(2): 311-334.

Lindsay, V. 2004. Computer-assisted qualitative data analysis: Application in an export study. In R. Marschan-Piekkari \& C. Welch (Eds.), Handbook of qualitative research methods for international business: 486-506. Cheltenham: Edward Elgar.

Lu, C. S., \& Lin, C. C. 2014. The effects of ethical leadership and ethical climate on employee ethical behavior in the international port context. Journal of Business Ethics, 124(2): 209223.

Luo, Y. 2005. Corporate governance and accountability in multinational enterprises: Concepts and agenda. Journal of International Management, 11(1): 1-18. 
Luthar, H. K., \& Karri, R. 2005. Exposure to ethics education and the perception of linkage between organizational ethical behavior and business outcomes. Journal of Business Ethics, 61(4): 353-368.

McAuliffe, D. 2012. Ethical decision making. In M. Gray, J. Midgley, \& S. A. Webb (Eds.). The SAGE handbook of social work: 316-327. Thousand Oaks, CA: Sage.

McNichols, C. W., \& Zimmerer, T. W. 1985. Situational ethics: An empirical study of differentiators of student attitudes. Journal of Business Ethics, 4(3): 175-180.

Mendonca, M. 2001. Preparing for ethical leadership in organizations. Canadian Journal of Administrative Sciences, 18(4): 266-276.

Mensah, Y. W. 2014. An analysis of the effect of culture and religion on perceived corruption in a global context. Journal of Business Ethics, 121(2): 255-282.

Miles, M. B., \& Huberman, A. M. 1994. Qualitative data analysis: An expanded sourcebook, $2^{\text {nd }}$ edn., Thousand Oaks, CA: Sage.

Mulla, Z. R., \& Krishnan, V. R. 2014. Karma-yoga: The Indian model of moral development. Journal of Business Ethics, 123(2): 339-351.

Nair, A., Guldiken, O., Fainshmidt, S., \& Pezeshkan, A. 2015. Innovation in India: A review of past research and future direction. Asia Pacific Journal of Management, 32(4): 925-958.

Nell, P. C., Puck, J., \& Heidenreich, S. 2015. Strictly limited choice or agency?: Institutional duality, legitimacy and subsidiaries political strategies. Journal of World Business, 50(2): 302-311.

Nichols, P. M. 2009. Multiple communities and controlling corruption. Journal of Business Ethics, 88(4): 805-813.

Nielsen, B., \& Nielsen, S. 2011. The role of top management team international orientation in international strategic decision-making: the choice of foreign entry mode. Journal of World Business, 46(2): 185-193.

Nielsen, R. P., \& Massa, F. G. 2013. Reintegrating ethics and institutional theories. Journal of Business Ethics, 115(1): 135-147.

Önal, M. 2010. Wisdom (Hikmah) as a holistic basis for inter-religious education. In K. Engebretson, M. de Souza, G. Durka, \& L. Gearson (Eds.). International handbook of interreligious education. Volume 4: 221-234. New York: NY: Springer.

Pant, A., \& Ramachandran, J. 2017. Navigating identity duality in multinational subsidiaries: A paradox lens on identity claims at Hindustan Unilever 1959-2015. Journal of International Business Studies, 48(6): 664-692.

Patel, T., \& Schaefer, A. 2009. Making sense of the diversity of ethical decision making in business: An illustration of the Indian context. Journal of Business Ethics, 90(2): 171-186.

Peng, M. W. 2002. Towards an institution-based view of business strategy. Asia Pacific Journal of Management, 19(2-3): 251-267.

Pinto, J., Leana, C. R., \& Pil, F. K. 2008. Corrupt organizations or organizations of corrupt individuals? Two types of organization-level corruption. Academy of Management Review, 33(3): 685-709.

Powell, W. 2007. The new institutionalism. In S. Clegg \& J. Bailey (Eds.). The International Encyclopedia of Organization Studies: 975-979, Thousand Oaks, CA: Sage.

Prashantham, S. and Dhanaraj, C. 2015. MNE ties and new venture internationalization: Exploratory insights from India. Asia Pacific Journal of Management, 32(4): 901-924.

Rejchrt, P. and Higgs, M. 2015. When in Rome: How non-domestic companies listed in the UK may not comply with accepted norms and principles of good corporate governance. Does home market culture explain these corporate behaviours and attitudes to compliance? Journal of Business Ethics, 129(1): 131-159.

Richards, L. 1999. Using NVivo in qualitative research. London: Sage. 
Robertson, C., \& Fadil, P.A. 1999. Ethical decision making in multinational organizations: A culture-based model. Journal of Business Ethics, 19(4): 385-392.

Rodriguez, P., Siegel, A., Hillman, A., \& Eden, L. 2006. Three lenses on the multinational enterprise: Politics, corruption and corporate social responsibility. Journal of International Business Studies, 37(6): 733-746.

Rodriguez, P., Uhlenbruck, K., \& Eden, L. 2005. Corrupt governments matter: How corruption affects the entry strategies of multinationals. Academy of Management Review, 30(2): 383396.

Rosenzweig, P.M., \& Singh, J. V. 1991. Organizational environments and the multinational enterprise. Academy of Management Review, 16(2): 340-361.

Schwartz, M. S. 2013. Developing and sustaining an ethical corporate culture: The core elements. Business Horizons, 56(1): 39-50.

Scott, W. R. 2001. Institutions and organizations, $2^{\text {nd }}$ edn., Thousand Oaks, CA: Sage.

Selznick, P. 1948. Foundations of the theory of organization. American Sociological Review, 13(1): 25-35.

Shirodkar, V., \& Mohr, A.T. 2015. Resource tangibility and foreign firms' corporate political strategies in emerging economies: Evidence from India. Management International Review. 55(6): 801-825.

Silverman, D. 2000. Doing qualitative research: A practical handbook. London: Sage.

Srinivasan, V. 2011. Business ethics in the South and South East Asia. Journal of Business Ethics, 104(1): 73-81.

Steenkamp, J.B.E.M., de Jong, M.G., \& Baumgartner, H. 2010. Socially desirable response tendencies in survey research. Journal of Marketing Research, 47(2): 199-214.

Stone, J. D. 2001. The full spectrum synthesis bible: Wisdom quotes of the masters of all religions and spiritual paths. Lincoln, NE: Writers Club Press.

Strauss, A., \& Corbin, J. 1990. Basics of qualitative research: Grounded theory procedures and techniques, $1^{\text {st }}$ edn., Thousand Oaks, CA: Sage.

Strauss, A., \& Corbin, J. 1997. Basics of qualitative research: Grounded theory procedures and techniques, $3^{\text {rd }}$ edn., Thousand Oaks, CA: Sage.

Suddaby, R., Seild, D., \& Lê, J. K. 2013. Strategy-as-practice meets neo-institutional theory. Strategic Organization, 11(3), 329-344.

Süß, S., \& Kleiner, M. 2008. Dissemination of diversity management in Germany: A new institutionalist approach. European Management Journal, 26(1): 35-47.

Sun, S. L., Peng, M. W. and Tan, W. 2017. Institutional relatedness behind product diversification and international diversification. Asia Pacific Journal of Management, 34(2): 339-366.

The World Bank 2012. India Country Opinion Survey Report (July 2012 - June 2013).

Transparency International 2015a. Corruption by country/territory: India. Retrieved January 16, 2017, from https://www.transparency.org/country/IND.

Transparency International 2015b. Corruption perception index 2015. Retrieved January 16, 2017, from https://www.transparency.org/whatwedo/publication/cpi_2015.

Trotter, R. C., Day, S. G., \& Love, A. E. 1989. Bhopal, India and Union Carbide: The second tragedy. Journal of Business Ethics, 8(6): 439-454.

Tsai, J. J., Wang, C. H., \& Lo, H. J. 2014. Locus of control, moral disengagement in sport, and rule transgression of athletes. Social Behavior and Personality: An International Journal, 42(1): 59-68.

Treviño, L. K., Weaver, G. R., \& Reynolds, S. J. 2006. Behavioral ethics in organizations: A review. Journal of Management, 32(6): 951-990. 
Ufere, N., Perelli, S., Boland, R., \& Carlsson, B. 2012. Merchants of corruption: How entrepreneurs manufacture and supply bribes. World Development, 40(12): 2440-2453.

Vardaman, J. M., Gondo, M. B., \& Allen, D. G. 2014. Ethical climate and pro-social rule breaking in the workplace. Human Resource Management Review, 24(1): 108-118.

Vittal, N. 2003. Corruption in India: The roadblock to national prosperity. New Delhi, India: Academic Foundation.

Voegtlin, C., Patzer, M., \& Scherer, A. G. 2012. Responsible leadership in global business: A new approach to leadership and its multi-level outcomes. Journal of Business Ethics, 105(1): 1-16.

Wang, G., \& Hackett, R. 2016. Conceptualization and measurement of virtuous leadership: Doing well by doing good. Journal of Business Ethics, 137(2): 321-345.

Wang, L. C., Ahlstrom, D., Nair, A., \& Hang, R. Z. 2008. Creating globally competitive and innovative products: China's next Olympic challenge. SAM Advanced Management Journal, 73(3): 4-15.

Waples, E. P., Antes, A. L., Murphy, S. T., Connelly, S., \& Mumford, M. D. 2009. A metaanalytic investigation of business ethics instruction. Journal of Business Ethics, 87(1): 133151.

Weaver, G. R., \& Agle, B. R. 2002. Religiosity and ethical behavior in organizations: A symbolic interactionist perspective. Academy of Management Review, 27(1): 77-97.

Welch, C. L., Welch, D. E., \& Tahvanainen, M. 2008. Managing the HR dimension of international project operations. International Journal of Human Resource Management, 19(2): 205-222.

$\mathrm{Wu}, \mathrm{X} .2009$. Determinants of bribery in Asian firms: Evidence from the World Business Environment Survey. Journal of Business Ethics, 87(1): 75-88.

Young, M. N., Ahlstrom, D., Bruton, G. D., \& Rubanik, Y. 2011. What do firms from transition economies want from their strategic alliance partners?. Business Horizons, 54(2): 163-174.

Zhu, Y., Sun, L. Y., \& Leung, A. S. M. 2014. Corporate social responsibility, firm reputation, and firm performance: The role of ethical leadership. Asia Pacific Journal of Management, 31(4): 925-947. 


\section{Appendix: Schedule of interview questions}

1. Do you think that it is possible for businesses to be ethical? Explain 'why' or 'why not' using anecdotal evidence/examples.

2. What do you think make Indian business ethics unique? How is it different to business ethics in other countries? Please explain using examples.

3. India has been perceived as having high levels of corruption with evidence of the Indian business environment ranking very high on the Corruptions Perceptions Index (CPI) [\# 94 most corrupt out of 174 countries] and the Bribe Payers Index (BPI) [\# 18 out of 28 countries]. Why do you think that is so? Give reasons using examples.

4. What do you think are the obstacles for other executives to put into practice ethical principles/teachings? Are these obstacles mainly at the global, societal, institutional level, organizational level or managerial level or a combination? Explain in detail using anecdotal evidence/examples.

5. Do you find any obstacles in putting into practice these ethical principles/teachings? Are these obstacles mainly at the global, societal, institutional level, organizational level or managerial level or a combination? Identify and explain using examples.

6. Where do corruption, cronyism and nepotism stem from? Please explain using anecdotes.

7. Is it possible to eradicate unethical practices? Please justify your response using examples/anecdotes.

8. How can Indian multinational businesses implement ethical practices? What do they need to do? Provide suggestions and examples.

9. How should Indian executives implement those ethical principles?

10. How do you implement those ethical principles? 
Table 1: Summary of interviewees' background

\begin{tabular}{|c|c|c|c|c|c|c|c|c|c|c|}
\hline $\begin{array}{l}\mathrm{Sr} \\
\text { No }\end{array}$ & Position & Industry & Gender & Age & $\begin{array}{l}\text { Position } \\
\text { Tenure }\end{array}$ & $\begin{array}{l}\text { Industry } \\
\text { Tenure }\end{array}$ & Education & $\begin{array}{l}\text { Overseas } \\
\text { Education }\end{array}$ & Work Overseas & $\begin{array}{l}\text { Overseas } \\
\text { Tenure }\end{array}$ \\
\hline 1. & $\begin{array}{l}\text { Director of Finance and } \\
\text { Company Secretary }\end{array}$ & Information Technology & Male & $51-55$ & 12 & 27 & Doctorate & USA & $\begin{array}{l}\text { Dubai, Singapore, } \\
\text { Sri Lanka, Egypt, } \\
\text { Oman and Thailand }\end{array}$ & 7 years \\
\hline 2. & $\begin{array}{l}\text { Chairman and Managing } \\
\text { Director }\end{array}$ & Pharmaceuticals & Male & $>60$ & 30 & 34 & Masters & - & Ukraine & 1.5 years \\
\hline 3. & Technical advisor & Automotive & Male & $>60$ & 8 & 41 & Bachelors & $\begin{array}{l}\text { Diploma } \\
\text { courses } \\
\text { from UK, } \\
\text { Germany, } \\
\text { USA }\end{array}$ & $\begin{array}{l}\text { UK, Germany, USA } \\
\text { and Japan }\end{array}$ & Short trips \\
\hline 4. & Assistant General Manager & Renewable Industry & Male & $31-35$ & 10 & 12 & Masters & Australia & $\begin{array}{l}\text { Australia and } \\
\text { Denmark }\end{array}$ & $\begin{array}{l}8 \text { months }- \\
2.5 \text { years }\end{array}$ \\
\hline 5. & $\begin{array}{l}\text { Additional General } \\
\text { Manager (Heading Gujarat) }\end{array}$ & Heavy Engineering & Female & $51-55$ & 15 & 28 & Masters & - & - & - \\
\hline 6. & Manager - TPM & Automobile Industry & Male & $31-35$ & 3 & 10 & Masters & - & Italy & 1.5 years \\
\hline 7. & Vice President & Shipping and Logistics & Female & $46-50$ & 10 & 28 & Masters & Sweden & - & - \\
\hline 8. & $\begin{array}{l}\text { Founder, Managing } \\
\text { Director and Chief } \\
\text { Executive Officer }\end{array}$ & Information Technology & Female & $46-50$ & 12 & 27 & Masters & - & - & - \\
\hline 9. & Managing Director & Information Technology & Male & $36-40$ & 15 & 15 & Bachelors & - & - & - \\
\hline 10. & $\begin{array}{l}\text { Chairman and Managing } \\
\text { Director }\end{array}$ & Engineering & Male & $51-55$ & 3 & 25 & Masters & USA & - & - \\
\hline 11. & Head IT Infrastructure & Manufacturing & Male & $31-35$ & 5 & 14 & Masters & - & Italy & 1 month \\
\hline 12. & Head of Sales & Telecom & Male & $41-45$ & 1 & 9 & Masters & - & Dubai and Bahrain & 4 years \\
\hline 13. & Global IT Head & Pharmaceuticals & Male & $41-45$ & 6 & 18 & Masters & - & $\begin{array}{l}\text { US, UK and } \\
\text { Malaysia }\end{array}$ & 7 months \\
\hline 14. & $\begin{array}{l}\text { Founder and Managing } \\
\text { Director }\end{array}$ & Travel and Tourism & Female & $36-40$ & 3 & 4 & Bachelors & - & $\begin{array}{l}\text { Hong Kong, Dubai, } \\
\text { Sri Lanka, Turkey }\end{array}$ & \begin{tabular}{|l|} 
Short \\
business \\
trips
\end{tabular} \\
\hline 15. & Senior Manager HR & Healthcare & Female & $31-35$ & $<1$ & 12 & Masters & - & - & - \\
\hline 16. & Head Corporate Affairs & Information Technology & Female & $46-50$ & 1.5 & $4-5$ & Masters & - & - & - \\
\hline 17. & $\begin{array}{l}\text { Senior Project Manager of } \\
\text { Business Intelligence and } \\
\text { Analytics }\end{array}$ & Information Technology & Female & $36-40$ & 4 & 10 & Masters & - & $\begin{array}{l}\text { UK and Northern } \\
\text { Ireland }\end{array}$ & $\begin{array}{l}2 \text { or } 3 \text { weeks } \\
\text { for business } \\
\text { tour }\end{array}$ \\
\hline 18. & Chief of Laboratory & Healthcare & Female & $36-40$ & 3 & 11 & Doctorate & - & - & - \\
\hline
\end{tabular}




\begin{tabular}{|c|c|c|c|c|c|c|c|c|c|c|}
\hline 19. & \begin{tabular}{|l} 
General Manager \\
Information Technology
\end{tabular} & Infrastructure & Male & $41-45$ & 1 & 1 & Masters & - & - & - \\
\hline 20. & Chief Information Officer & Information Technology & Male & $>60$ & $<1$ & 40 & Masters & - & - & - \\
\hline 21. & Chief Executive Officer & Tyre Manufacturing & Male & $46-50$ & 18 & 18 & Bachelors & - & Dubai & 8 years \\
\hline 22. & Founder Member & Chip Designing & Male & $>60$ & 18 & 40 & Bachelors & - & $\begin{array}{l}\text { Entire Europe, USA, } \\
\text { Nordic countries }\end{array}$ & \begin{tabular}{|l|} 
Short \\
business \\
trips \\
\end{tabular} \\
\hline 23. & Deputy General Manager & Cement Manufacturing & Male & $41-45$ & 15 & 7 & Masters & - & $\begin{array}{l}\text { Saudi Arabia, Egypt, } \\
\text { Mozambique, } \\
\text { Kenya, Ethiopia, } \\
\text { Djibouti, Indonesia. } \\
\end{array}$ & $\begin{array}{l}\text { Project } \\
\text { based trips }\end{array}$ \\
\hline 24. & National Business Head & Information Technology & Female & $31-35$ & 8 & 12 & Masters & - & - & - \\
\hline 25. & $\begin{array}{l}\text { Head of Recruitments and } \\
\text { Assessments }\end{array}$ & Education & Female & $41-45$ & 2 & 2 & Masters & - & - & - \\
\hline 26. & Chief Financial Officer & $\begin{array}{l}\text { Fast Moving Consumer } \\
\text { Goods }\end{array}$ & Male & $51-55$ & 3.5 & 8 & Masters & - & USA and Mexico & - \\
\hline 27. & Managing Director & Healthcare & Female & $36-40$ & 18 & 18 & Masters & - & Australia & 3 years \\
\hline 28. & General Manager & Petroleum & Female & $41-45$ & 8 & 8 & Doctorate & - & USA & 4-5 months \\
\hline 29. & Senior General Manager & $\begin{array}{l}\text { Business Services } \\
\text { (Consultancy) }\end{array}$ & Male & $51-55$ & 16 & 35 & Masters & - & - & - \\
\hline 30. & $\begin{array}{l}\text { Senior Manager Corporate } \\
\text { Communications }\end{array}$ & Coal Mining & Male & $51-55$ & 17 & 23.5 & Masters & - & - & - \\
\hline 31. & Senior Vice President & $\begin{array}{l}\text { Manufacturing } \\
\text { (pipes/alloys) }\end{array}$ & Male & $51-55$ & 15 & 21 & Masters & USA & Germany and USA & 5 years \\
\hline 32. & $\begin{array}{l}\text { Senior Vice President } \\
\text { (Marketing) }\end{array}$ & $\begin{array}{l}\text { Information Technology } \\
\text { Services }\end{array}$ & Male & $36-40$ & 12 & 16 & Masters & - & Australia and USA & Short trips \\
\hline 33. & Head of Logistics & $\begin{array}{l}\text { Fast Moving Consumer } \\
\text { Goods }\end{array}$ & Male & $51-55$ & 5 & 30 & Bachelors & - & $\begin{array}{l}\text { USA and Several } \\
\text { European Countries }\end{array}$ & 2 years \\
\hline 34. & \begin{tabular}{|l} 
Managing \\
Director/Regional Head
\end{tabular} & Manufacturing & Male & $46-50$ & 22 & 22 & Masters & USA & - & - \\
\hline 35. & $\begin{array}{l}\text { Senior Vice President } \\
\text { (Marketing) }\end{array}$ & $\begin{array}{l}\text { Information Technology } \\
\text { Services }\end{array}$ & Male & $46-50$ & 2 & 25 & Masters & - & $\begin{array}{l}\text { Singapore, Korea, } \\
\text { Japan, USA, UK, } \\
\text { Australia }\end{array}$ & Short trips \\
\hline 36. & Chief Financial Officer & Manufacturing & Male & $56-60$ & 10 & 35 & Masters & - & - & - \\
\hline 37. & Senior Editor & Media & Male & $36-40$ & 1 & 7 & Masters & Australia & - & - \\
\hline 38. & Head (Software Design) & Information Technology & Male & $41-45$ & 15 & 24 & Masters & England & England & 2 years \\
\hline 39. & $\begin{array}{l}\text { Vice President (Corporate } \\
\text { Cards) }\end{array}$ & Banking & Male & $46-50$ & 18 & 25 & Masters & - & - & - \\
\hline 40. & \begin{tabular}{|l} 
Director (Human \\
Resources)
\end{tabular} & Automobiles & Male & $51-55$ & 3 & 28 & Masters & - & - & - \\
\hline
\end{tabular}


Table 2: An illustration of the open coding process: Institutional and managerial level strategies for ethical decision-making

\begin{tabular}{|c|c|c|c|}
\hline Step 1: Underline key terms on the quotes & $\begin{array}{l}\text { Step 2: Restating key } \\
\text { phrases }\end{array}$ & $\begin{array}{l}\text { Step 3: Developing and } \\
\text { naming concepts }\end{array}$ & $\begin{array}{l}\text { Step 4: Developing and } \\
\text { naming categories }\end{array}$ \\
\hline $\begin{array}{l}\text { [Interview \#7] ...I think we have lot of ethical practices that is one of the reasons why we Indian } \\
\text { multinationals are doing so well today. All the multinationals from other countries when they come } \\
\text { into India they do so well. I think a lot of it goes into the ethical practices that we follow here. I } \\
\text { don't know as to what a multinational does to implement ethical practices. So Indian Multinationals } \\
\text { implement transparency, they follow clear policies as laid down this reduces the scope of unethical } \\
\text { practices like sealing all the loop holes... Yes, we have audit of all the systems, like we have audit } \\
\text { of all the accounts, we have audits of all the bookings we do, we have audit of every activity that } \\
\text { is done. So the company maintains verification and check on everything. Has proper control. }\end{array}$ & $\begin{array}{l}\text { Defined ethical practices } \\
\text { Follow ethical practices } \\
\text { Transparency and implementation of } \\
\text { transparency } \\
\text { Audit verification and checks } \\
\text { Proper control }\end{array}$ & Regulative & Institutional level strategies \\
\hline $\begin{array}{l}\text { [Interview\#13] ... No actually in the above particular case which I was talking about being ignorant } \\
\text { about what is the expectation and what are the needed area to actually get compliance on that. So } \\
\text { we have asked the US FDA representative to kindly let us know what are the procedures to help us } \\
\text { out, what are their expectations and what are their governance, mechanism so that we aware and } \\
\text { fulfil that requirement. If suppose we don't get trained on that, there could be a chance were we } \\
\text { slip all these things. So we been trained and we been certified on system validation and that is how } \\
\text { we have got the certification and that is how start supply to the European market. So one part is } \\
\text { that something is the governance which is not been properly trained or aware to the society or the } \\
\text { corporate world. There are chances were there could be some slip on that point. So it is the } \\
\text { government's responsibility to make aware regarding what are the procedures and the policy in } \\
\text { term of the government, policies on } 27001 \text { IT Act, if you are not keeping aware my management } \\
\text { or my users. So there will be an ignorance of the procedure and policy which would directly land } \\
\text { to me actually, because owing that domain if I am not able to train and create awareness about that } \\
\text { security thing then that will be a foul on the whole system. So it is much important for the domain } \\
\text { perspective that they create that awareness about that compliances and policies. }\end{array}$ & $\begin{array}{l}\text { Meeting expectations } \\
\text { Obtaining certification } \\
\text { Benchmarking } \\
\text { Creating awareness about compliance } \\
\text { procedures and systems }\end{array}$ & Normative & \\
\hline $\begin{array}{l}\text { [Interview } \# 17] \text {...no, we cannot completely eradicate unethical practices altogether but we can } \\
\text { control it, minimize it by following ethical practices and by making others follow them. Also in } \\
\text { order to run business there has to be something, which has to be sacrificed, and that can be ethical } \\
\text { practices too. It is not possible to eradicate altogether but yes, we can minimize it. It depends from } \\
\text { person to person and organization to organization. I told you about Ratan Tata [Former Chairman } \\
\text { of Tata Group] and Shiv Nadar [Founder and Chairman of HCL Enterprise]. They are worried } \\
\text { about their overall personality, their overall objectivity and their overall commitment to the society. } \\
\text { They wouldn't mind losing one or two customers or probably a big part of their business but they } \\
\text { would never follow unethical principles by being dishonest or playing with the law of the country. } \\
\text { But there are certain groups of people who don't mind going any distance in order to gain an edge } \\
\text { over the others. Competitive edges over the others. They will go to an extent like cheating } \\
\text { customers, showing them what they don't have or committing them what they cannot achieve or } \\
\text { going against the law of the country... so for me, people like Shiv Nadar and Ratan Tata are the } \\
\text { most ethical people who are running this business. Because their motto towards this industry and } \\
\text { their commitment towards the people of India, they are working towards this. So, it is, probably }\end{array}$ & $\begin{array}{l}\text { Follow ethical practices and make } \\
\text { others follow } \\
\text { Isomorphism } \\
\text { Cultural values and shared } \\
\text { understanding }\end{array}$ & Cognitive & \\
\hline
\end{tabular}


that is what is driving them towards these ethics and follow these ethics. And it is the Indian culture basically.

[Interview \#12] ... multiple things, at the time of recruitment, proper screening, proper reference check, induction, when he is finally selected, proper induction, dissemination of code of conduct, meeting with new employees, finally code of conduct, making norms i.e. if you violate this code of conduct then what are the repercussions which can happen. All those things can be discussed and explained to him at periodical levels and at multiple times in his office tenure in the organization. Our company follows these kinds of ethical practices.

[Interview \#15] ....we should make sure to be impartial, take care of the employees, we as leaders should follow ethical practices, which by watching us our subordinates will follow us. When the manager follows ethical practices he will make sure that his team member also follows ethical practices. We have to govern them, train them. Lot of counselling has to be given, lot of examples have to be set. We have to train them a lot in following ethical practices.

[Interview \#31] ... Another solution is having an ethical mindset which focuses on ethical values. You know it is critical to develop this type of a mindset which allows you to filter unethical thoughts and selectively apply morally sound and ethically appropriate practices. For everyone

the corporation to subscribe to this view, you need to encourage ethical mindset development.

Prudent recruitment, selection and induction procedures

Education

On-going training and development
Human resource management
.

Role model

Leadership

Ethical values

Ethical mindset

Apply morally sound and ethically

appropriate practices
Ethical mindset cultivation and

development
Managerial level strategies 
Figure 1: A Theoretical Model of Ethical Decision-Making in Indian MNCs

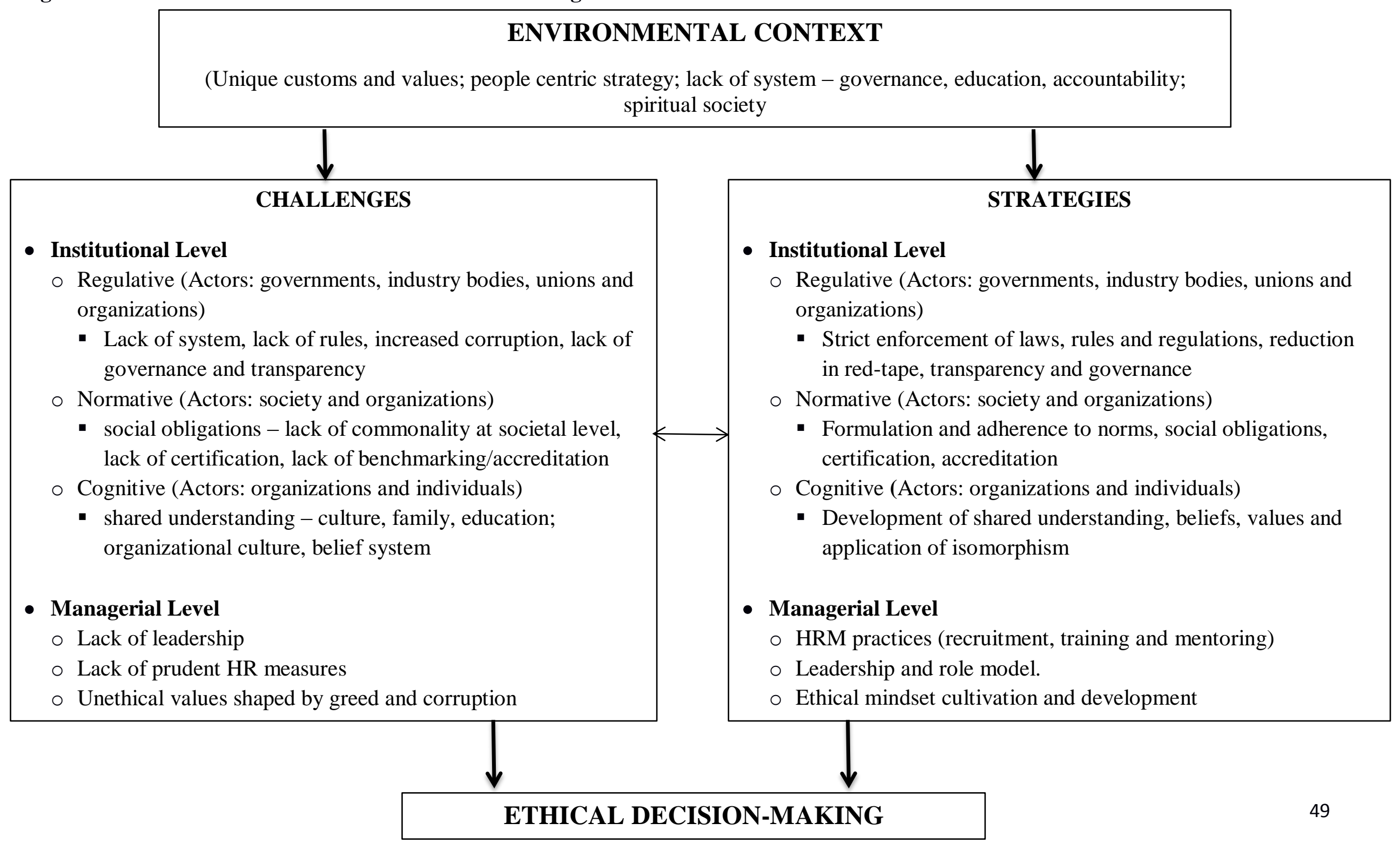

